\title{
Effects of Fiber Reinforcements on the Strength of Shotcrete
}

\author{
Syed Azmat Ali Shah ${ }^{1}$, Mian Asfahan Ali Gul', Tayyab Naqash" ${ }^{3, *}$, Zeeshan Khan ${ }^{4}$, Muhammad Rizwan ${ }^{2}$ \\ ${ }^{1}$ Centre for Disaster Preparedness and Management, University of Peshawar, Pakistan \\ ${ }^{2}$ Department of Civil Engineering, University of Engineering and Technology Peshawar, Pakistan \\ ${ }^{3}$ Department of Civil Engineering, Islamic University of al-Madinah al-Munawara, KSA \\ ${ }^{4}$ City University of Science and Information Technology Peshawar, Pakistan \\ *Corresponding Author: tayyab@iu.edu.sa, engr.tayyabnaqash@gmail.com
}

Received December 8, 2020; Revised January 15, 2020; Accepted February 18, 2021

\section{Cite This Paper in the following Citation Styles}

(a): [1] Syed Azmat Ali Shah, Mian Asfahan Ali Gul, Tayyab Naqash, Zeeshan Khan, Muhammad Rizwan, "Effects of Fiber Reinforcements on the Strength of Shotcrete," Civil Engineering and Architecture, Vol. 9, No. 1, pp. 176 - 184, 2021. DOI: 10.13189/cea.2021.090115.

(b): Syed Azmat Ali Shah, Mian Asfahan Ali Gul, Tayyab Naqash, Zeeshan Khan, Muhammad Rizwan (2021). Effects of Fiber Reinforcements on the Strength of Shotcrete. Civil Engineering and Architecture, 9(1), 176 - 184. DOI: 10.13189/cea.2021.090115.

Copyright $\bigcirc 2021$ by authors, all rights reserved. Authors agree that this article remains permanently open access under the terms of the Creative Commons Attribution License 4.0 International License

\begin{abstract}
Like concrete, Shotcrete poorly performs when subjected to tension; therefore, it experiences displacements and breaking when it is exposed to tensile loadings - adding fibers to concrete increases the ductility of Shotcrete. For this reason, two shotcrete mixes were prepared, plain, and reinforced with fibers (Fiber Reinforced Shotcrete, FRS). The results were looked at and recorded. Shotcrete with a strength of more than $35 \mathrm{MPa}$ were designed and prepared. Steel and polypropylene fibers of different weights and shapes are added to Shotcrete. After adding fibers to Shotcrete, Shotcrete with fascinating properties is produced after testing the samples for 7 and 28 days. The results stated that the tensile and compressive strength of Shotcrete enhanced with additional fibers. Shotcrete has indistinguishable properties compared to concrete, and adding of polypropylene fibers up-to $3 \mathrm{~kg} / \mathrm{m} 3$ disclosed a nearly $20 \%$ rise in the compressive strength of Shotcrete. The compressive strength diminished with an increase in the quantity of fiber past $3 \mathrm{~kg} / \mathrm{m}^{3}$. The tensile and flexural properties of Polypropylene Fiber Reinforced Shotcrete (PFRS) continued expanding with higher fiber quantity. Similarly, the compressive, tensile, and flexure strength of Shotcrete increased with an increase in the number of steel fibers.
\end{abstract}

Keywords Shotcrete, Polypropylene Fibers, Steel Fibers, Compressive Strength, Tensile Strength

\section{Introduction}

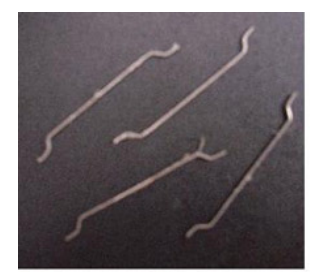

Hooked steel

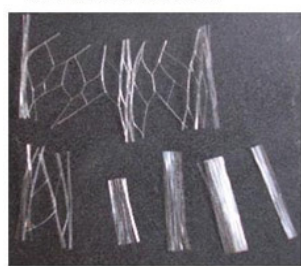

Polypropylene

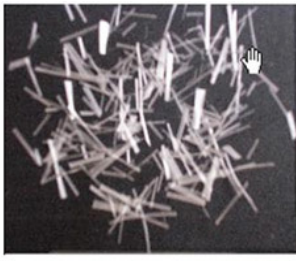

Glass

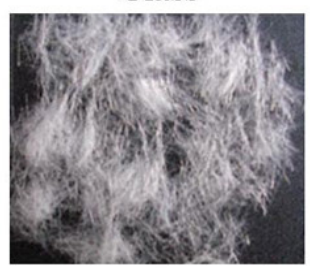

Polyester
Figure 1. Different types of fibers used for Shotcrete

Shotcrete is a mix of cement and fine sand applied hydraulically and compressed powerfully at high speed. Generally, the particle of grading size up-to $16 \mathrm{~mm}$ is utilized in shotcrete applications worldwide. In general, Shotcrete gain 70-80 \% of its strength within 7 days after placing [1]. Shotcrete experiences arrangement and compaction simultaneously due to the speed of its ejection from the nozzle. It is evident that concrete structures, except those when strengthened with reinforcement, are 
incapable of sustaining the load in tension. For this purpose, most researchers added fibers of different materials to enhance the tensile properties of concrete and Shotcrete. Many researchers adopted various artificial materials like polyvinyl alcohol, polypropylene fibers (PP), polyethylene, and polyamides, to strengthen the concrete to resist tension. For example, Banthia et al. [2] stated that fibers are offered in 3 forms: steel, glass, and synthetic fibers. The characteristic fibers are shown in Figure 1.

He described that Shotcrete having steel fibers must participate in a tensile strength up-to 1.0 $\mathrm{GPa}$ and tensile-modulus of $200 \mathrm{GPa}$. He also deliberated different forms of synthetic fibers. He noticed that these are made of Nylon, Polyethene, Rayon, Polypropylene, and Polyester. Nevertheless, Polypropylene has been mainly utilized in Shotcrete as fiber reinforcement. The addition of synthetic fibers diminishes the shrinkage cracks in Shotcrete. Prisco et al. [3] gave a definite examination of steel-fibers in Shotcrete [4].

$\mathrm{Xu}$ Yan et al. [5] concluded that mixing silica fume and steel-fiber could significantly improve bending toughness and splitting tensile, flexural, and shear strengths of wet Shotcrete. Different types and contents of steel fibers did not have a noticeable effect on wet Shotcrete's compressive strength. When silica fume and shear undaform steel-fiber are mixed, a $29 \%$ increase in the compressive strength is observed. In contrast, the splitting tensile, shear, flexural, and initial crack strength of combining the shear undaform steel fiber are about $10 \%$ higher than mixing the shear flat steel-fiber.

Le Hoang [6] investigated the effect on the uniaxial tensile and compressive behaviour of ultra-high-performance concrete (UHPC), considering $1.5 \%$ and $3 \%$ steel-fiber contents using different aspect ratios. No apparent change in the compressive strength and elastic-modulus was recorded; however, the post-peak behavior under compression was affected considerably. In terms of notched prisms under tension, no steel-fibre influence is noticed in the linear elastic stage. In contrast, the increase in steel-fibre content exerted a substantial effect on the fiber activation stage, but higher fibre efficiency values are achieved. Rahman et al. studied the influence of adding waste materials such as metal bottle caps and glass powder in concrete and observed an excellent increase in concrete strength [7][8].

Waseem Abbas et al. [9] investigated that adding different lengths of steel-fibers and content using increase water-to-cement ratios caused a considerable variation in concrete's mechanical properties. A rise of $0.5 \%$ to $1.5 \%$ in fiber-content advances the flexural strength by $3 \%$ to $124 \%$ for fibers having a smaller aspect ratio of 65 . They also observed a $10-25 \%$ increase in compressive strength and about 31 to $47 \%$ indirect tensile strength. For a higher aspect ratio such as 80 , a $140 \%$ increase in flexural strength was observed compared to plain concrete. An analytical model for the stress-strain relationship of fiber reinforced concrete under compression is proposed. They found a good agreement between the proposed model and the experimental results [10]. The fibers are accessible in various characteristics, shapes, and dimensions. The length of fibers should be multiple times the maximum aggregate size to give proper bonds and cover paste between fibers in Shotcrete. Closely spaced steel fibers result in a strong Steel Fiber Reinforced Shotcrete (SFRS). Small diameter fibers result in more slender fibers, which densify the Shotcrete with more fibers [11]. The stable bond features among steel-fibers and Shotcrete guarantee the shift of the tensile stresses fibers.

The bond between Shotcrete and steel-fibers can be enhanced by selecting a realistic shape of the fiber. Squeezed wires, amplified ends, and hooks are some of the locally accessible forms. The effectiveness of SFRS relies on the rigidity of steel-fibers; therefore, higher rigidity of steel fiber maintains distance from fiber crack. Research in the mix design has created high-quality Shotcrete, which requires considerably advanced steel fibers' strength to create higher rigidity [12]. In Pakistan, hydropower projects like Neelum-Jehlum, Patrind, and Daral Khwar used Fiber-Reinforced-Shotcrete (FRS). The use of these FRS has prominence on the compression strength of Shotcrete. In contrast, tensile strength is considered higher for not using wire mesh. Generally, there are small arrangements for tensile and flexure testing at sites; therefore, it requires a suitable quantity of fiber reinforcement to be used in such projects [13][14].

\section{Experimental Activity}

Effects of fibers on structural properties such as tensile, compressive, and flexural strength of Shotcrete are studied in this research. The results obtained are compared with plain Shotcrete, and the feasibility of Shotcrete obtained by adding fibers is studied in the actual construction field. Shotcrete mix is set up to accomplish a target strength of more than $35 \mathrm{MPa}$. Mix design of Shotcrete involved workable slump and w/c ratio with water reducing agents and accelerators for fast setting of Shotcrete. In light of these perceptions, the "sand" to "aggregate" ratio of 0.63 by weight is followed and used in shotcrete mix design for plain and Shotcrete reinforced using steel and propylene fibers to improve the tensile strength. The adopted weight of steel fibers is $40 \mathrm{~kg} / \mathrm{m}^{3}, 45 \mathrm{~kg} / \mathrm{m}^{3}$, and $50 \mathrm{~kg} / \mathrm{m}^{3}$. These were hooked $(25 \mathrm{~mm}$ in length with $0.4 \mathrm{~mm}$ diameter of having an aspect ratio of 62.4) and conform to ASTM A 820 [15]. Similarly, the quantity of polypropylene fibers are $1.0 \mathrm{~kg} / \mathrm{m}^{3}, 3.0 \mathrm{~kg} / \mathrm{m}^{3}$ and $5.0 \mathrm{~kg} / \mathrm{m}^{3}$. Polypropylene fibers of length $12 \mathrm{~mm}$ and diameter of $0.018 \mathrm{~mm}$ with an aspect ratio of 666.67 are used. The typical arrangement of both fibers is shown in Figure 2 and Figure 3. A 
standard shotcrete panel 30inch by 8inch was made of timber for the Shotcrete while cores and beams were drilled out and extracted to ASTM C1604 [16].

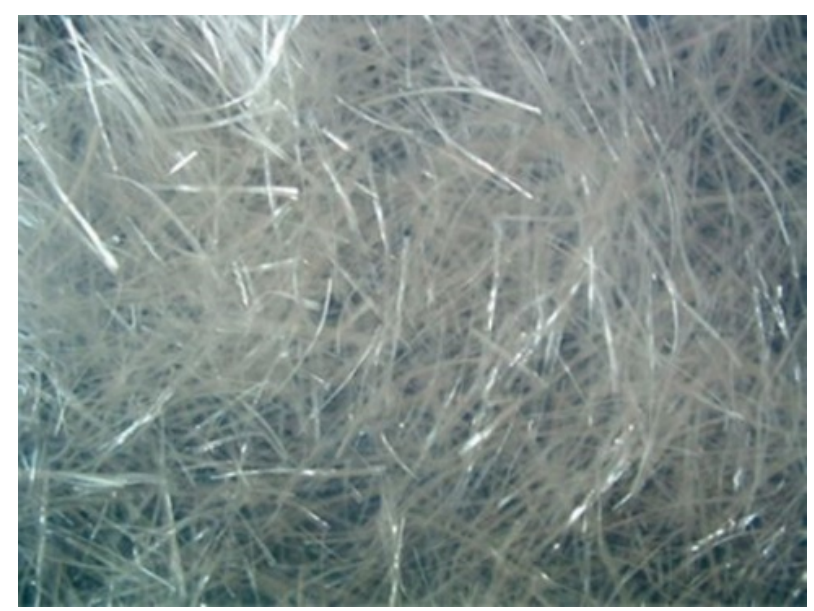

Figure 2. Polypropylene Fibers to be added to the concrete

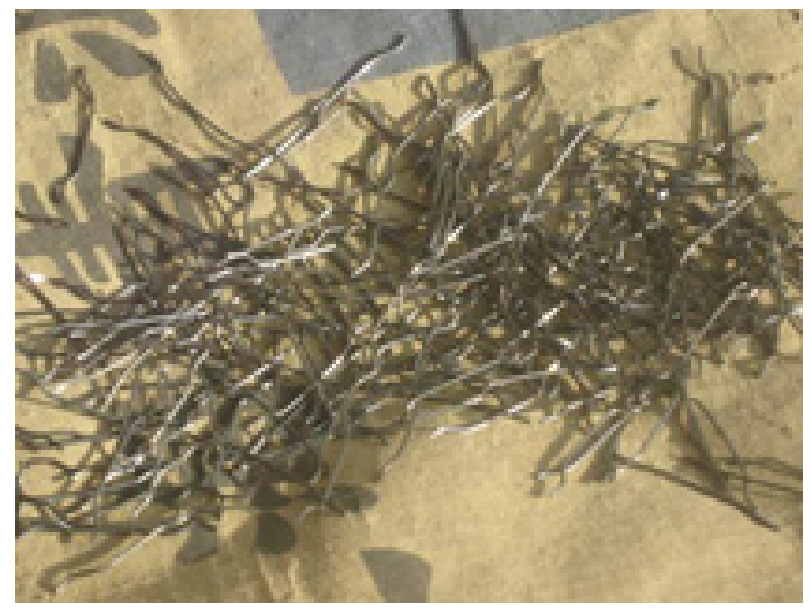

Figure 3. Hooked Steel Fibers to be added as reinforcing fibers to concrete

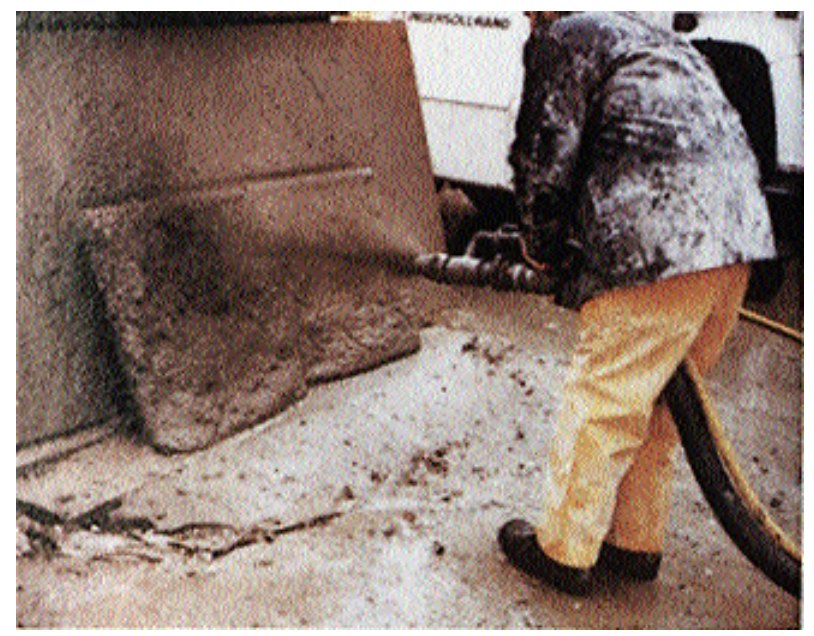

Figure 4. Panels sprayed with Shotcrete

Each shotcrete mix is shot in a separate panel with a nozzle perpendicular to the panel surface. A test panel sprayed with Shotcrete is shown in Figure 4.

Cylinder-shaped specimens of 8inch $\mathrm{x}$ 4inch were obtained both for compressive and tensile testing, according to ASTM C 1604. Similarly, a particular type of wood mold having dimensions of 21x $6 \times 6$ (in inches) for casting beams required for flexural strength. The compressive, tensile, and flexural testing for plain and fibers reinforced Shotcrete (FRS) specimens are performed with the results obtained, as discussed in the forthcoming section.

\section{Results and Discussion}

The designed mix both for plain and reinforced Shotcrete is shot for all panels keeping in view the same angle of the shoot and the same distance for all panels by shotcrete pump operator (at Daral Khwar Hydropower Project Bahrain, Swat). Cores extracted as per ASTM C 1604 were utilized for the Compressive strength test and split cylinder test, while beams prepared are used for the flexural strength test. The quantity of steel and propylene reinforcement is shown in Table 1.

Table 1. Fiber Reinforcement considered for the experiment

\begin{tabular}{|c|c|c|c|}
\hline \multirow{2}{*}{ Shotcrete Type } & \multicolumn{4}{|c|}{ Quantity of Fiber $\left(\mathrm{kg} / \mathrm{m}^{3}\right)$} \\
\cline { 2 - 4 } & Case 1 & Case 2 & Case 3 \\
\hline PS (Plain Shotcrete) & \multicolumn{3}{|c|}{ Without any addition of Fiber } \\
\hline $\begin{array}{c}\text { SFRS (Steel Fiber } \\
\text { Reinforced Shotcrete) }\end{array}$ & 40 & 45 & 50 \\
\hline $\begin{array}{c}\text { PRS (Polypropylene } \\
\text { Reinforced Shotcrete) }\end{array}$ & 1.0 & 3.0 & 5.0 \\
\hline
\end{tabular}

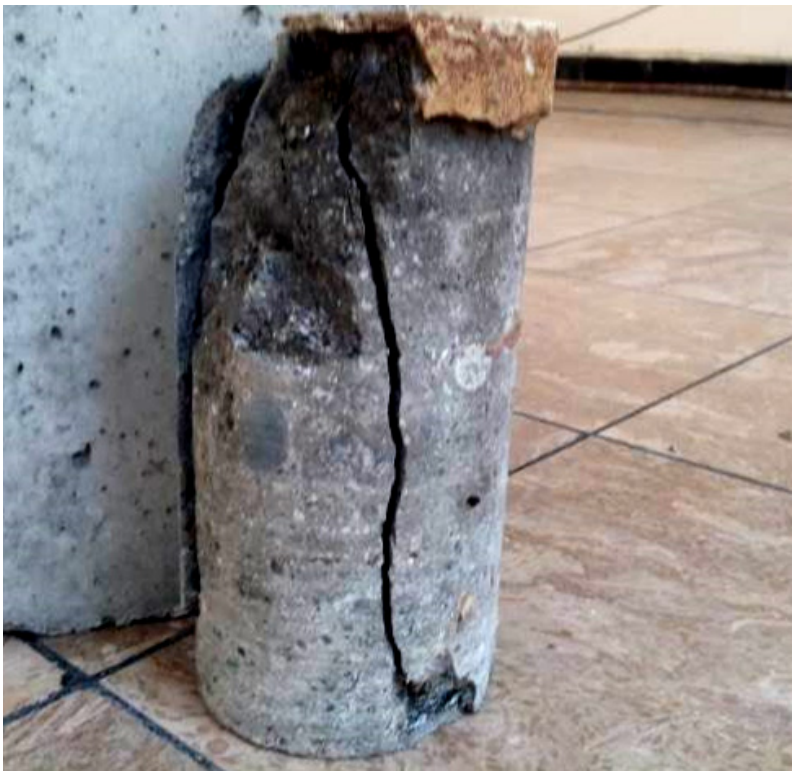

Figure 5. Failure form of plain shotcrete specimens

Universal Testing Machine (UTM) is used to investigate the compressive strength of the fabricated specimens. A typical cone and split type failure pattern are observed for plain Shotcrete. However, in the case of steel 
and propylene reinforced Shotcrete, line cone and shear-type failure pattern are recorded. These patterns for the three cases are shown in Figure 5 for PS, Figure 6 for SFRS, and Figure 7 for PFRS.

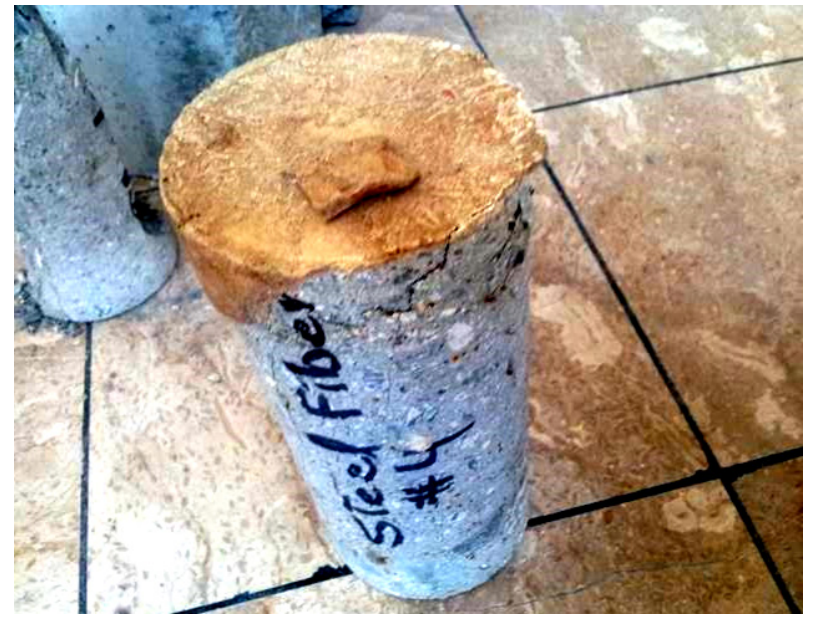

Figure 6. Failure form of SFRS Specimen

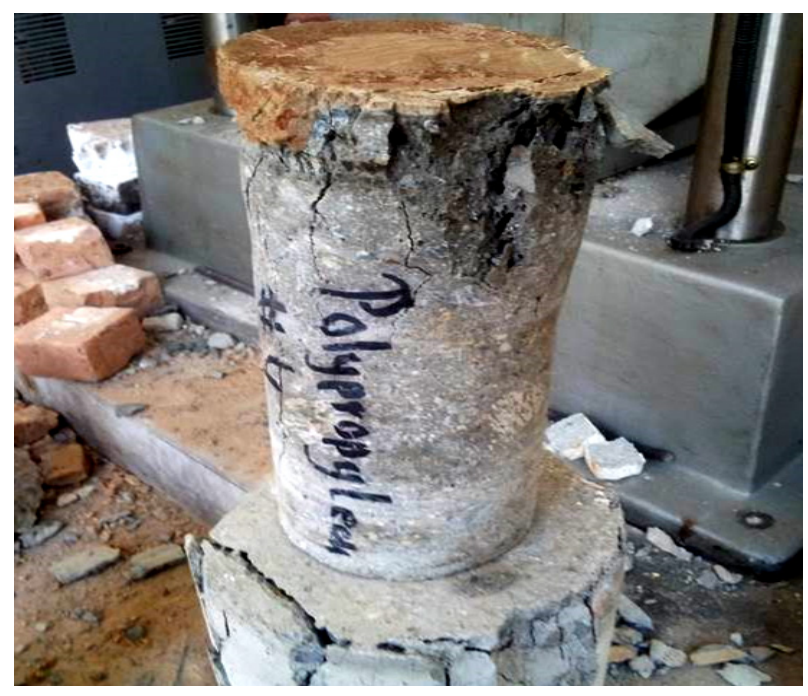

Figure 7. Failure form of PFRS Specimen

Table 2 shows the 7- and 28-day compressive strength test results for each type of Shotcrete.

Table 2. Compressive strength for the tested specimen on 7 and 28 days

\begin{tabular}{|c|c|c|c|c|c|}
\hline $\begin{array}{l}\text { Type of } \\
\text { Shotcrete }\end{array}$ & $\begin{array}{l}\text { Fiber quantity } \\
\qquad\left(\mathrm{kg} / \mathrm{m}^{3}\right)\end{array}$ & $\begin{array}{c}\text { Mean } 7 \text { days } \\
\text { Compressive Strength } \\
(\mathrm{MPa}) \\
\end{array}$ & $\begin{array}{c}\text { Percentile } \\
\text { Increase } \\
(\%) \\
\end{array}$ & $\begin{array}{c}\text { Mean } 28 \text { days } \\
\text { Compressive Strength } \\
\text { (MPa) } \\
\end{array}$ & $\begin{array}{c}\text { Percentile } \\
\text { Increase } \\
(\%) \\
\end{array}$ \\
\hline PS & 0.0 & 29.4 & - & 35.6 & - \\
\hline \multirow{3}{*}{ SFRS } & 40.0 & 30.7 & 4.5 & 37.1 & 4.3 \\
\hline & 45.0 & 32.0 & 9.1 & 38.7 & 8.9 \\
\hline & 50.0 & 33.0 & 12.4 & 39.9 & 12.2 \\
\hline \multirow{3}{*}{ PFRS } & 1.0 & 31.9 & 8.6 & 38.6 & 8.5 \\
\hline & 3.0 & 35.5 & 21.0 & 42.9 & 20.7 \\
\hline & 5.0 & 34.2 & 16.6 & 41.4 & 16.4 \\
\hline
\end{tabular}



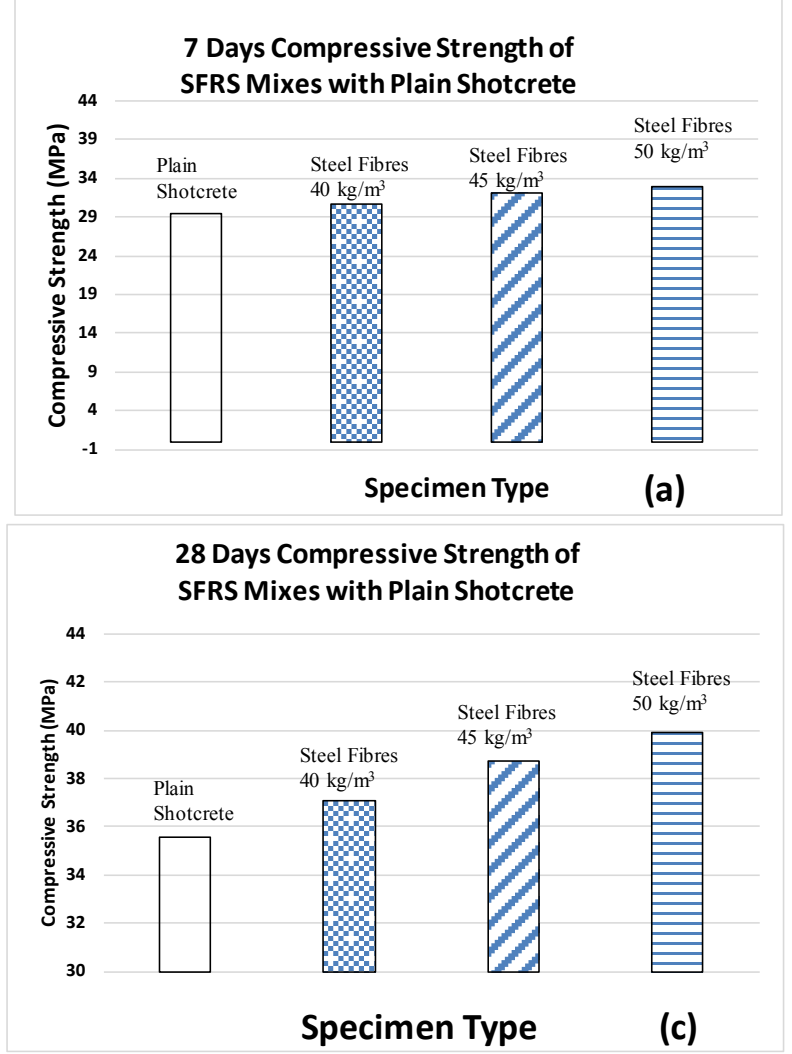

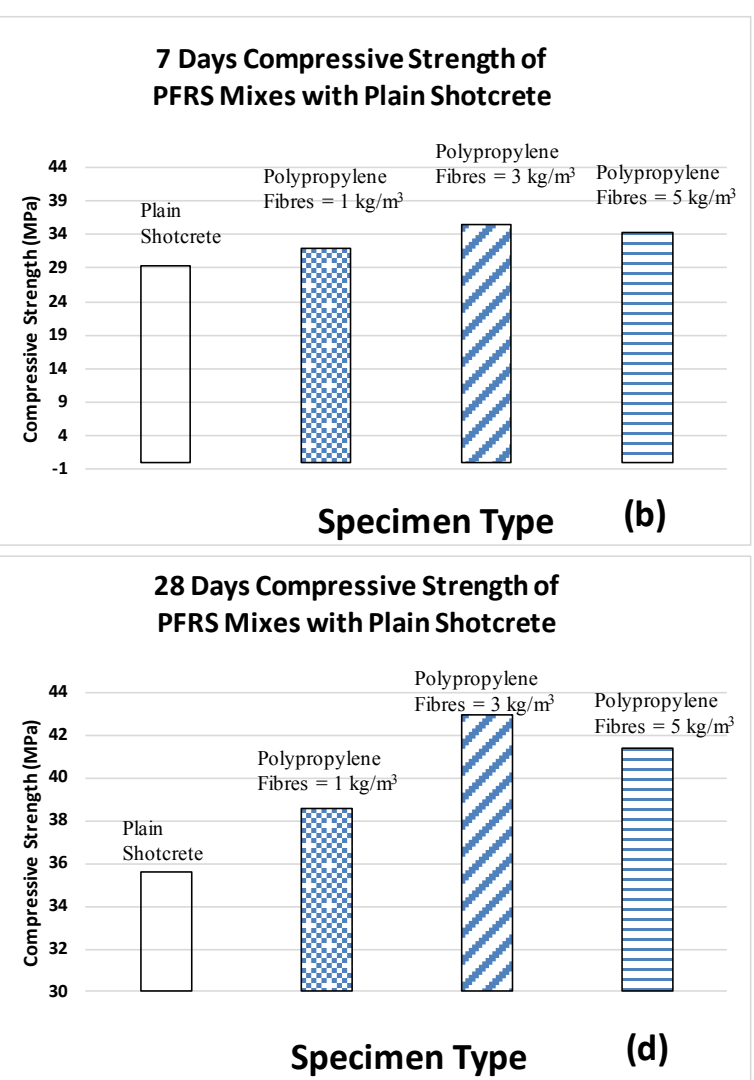

Figure 8. Comparison of compressive strengths (a) 7 days using SFRS, (b) 7 days using PFRS, (c) 28 days using SFRS, and (d) 28 days using PFRS

The comparison of compressive strength obtained for SFRS and PFRS for 7 days are shown by Figure 8 (a) and Figure 8 (b), respectively, whereas for 28 days are shown by Figure 8 (c) and Figure 8 (d).

The 7 days compressive strength of cylinders without fibers is $29.4 \mathrm{Mpa}$, which varies from $4.5 \%$ to $12.4 \%$ for SFRS and $8.6 \%$ to $16.6 \%$ for PFRS, as shown in Table 2 . Similarly, the 28 days compressive strength of cylinders without is $35.6 \mathrm{Mpa}$ and varies from $4.2 \%$ to $12.2 \%$ for SFRS and $8.5 \%$ to $16.4 \%$ for PFRS (See Table 2). The rationale behind the enhancement in strength is that randomly-oriented fibers arrest a microcracking mechanism and limit crack propagation, thus improving strength.

According to ASTM C1604-1604M, the split tensile test is conducted on a 4-inch (101.mm) diameter, 8 inches $(203.2 \mathrm{~mm})$ long Shotcrete extracted drilled core. After the test, the specimen is split into two halves (see Figure 9), which showed that fiber-reinforced Shotcrete is split at a higher strength than plain Shotcrete. The split tensile strength results for 7 and 28 days are shown in Table 3 for each type of Shotcrete.

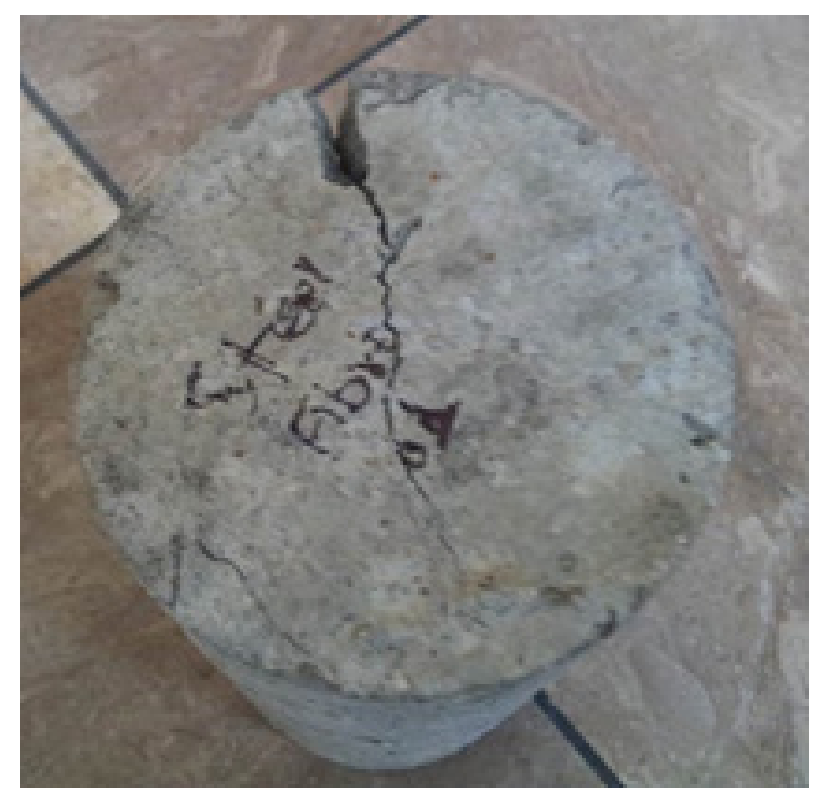

Figure 9. Core Failure pattern 
Table 3. Tensile Strength Test Results for 7- and 28-Days

\begin{tabular}{|c|c|c|c|c|c|}
\hline $\begin{array}{c}\text { Type of } \\
\text { Shotcrete }\end{array}$ & Fiber $\left(\mathbf{k g} / \mathbf{m}^{\mathbf{3}}\right)$ & $\begin{array}{c}\text { Mean 7 days split } \\
\text { tensile strength (MPa) }\end{array}$ & $\begin{array}{c}\text { Percentile } \\
\text { Increase (\%) }\end{array}$ & $\begin{array}{c}\text { Mean 28 days split } \\
\text { tensile strength (MPa) }\end{array}$ & $\begin{array}{c}\text { Percentile } \\
\text { Increase (\%) }\end{array}$ \\
\hline Plain Shotcrete & 0.0 & 1.4 & - & 2.0 & - \\
\hline \multirow{3}{*}{ SFRS } & 40.0 & 1.8 & 24.4 & 3.2 & 61.3 \\
\cline { 2 - 6 } & 45.0 & 2.6 & 84.7 & 3.9 & 101.8 \\
\cline { 2 - 6 } & 50.0 & 3.2 & 121.2 & 4.2 & 114.4 \\
\hline \multirow{3}{*}{ PFRS } & 1.0 & 1.9 & 34.9 & 3.1 & 60.4 \\
\cline { 2 - 6 } & 3.0 & 3.3 & 134.2 & 3.8 & 93.5 \\
\cline { 2 - 6 } & 5.0 & 3.7 & 163.0 & 4.1 & 109.3 \\
\hline
\end{tabular}

7 Days Tensile Strength of SFRS Mixes with Plain Shotcrete
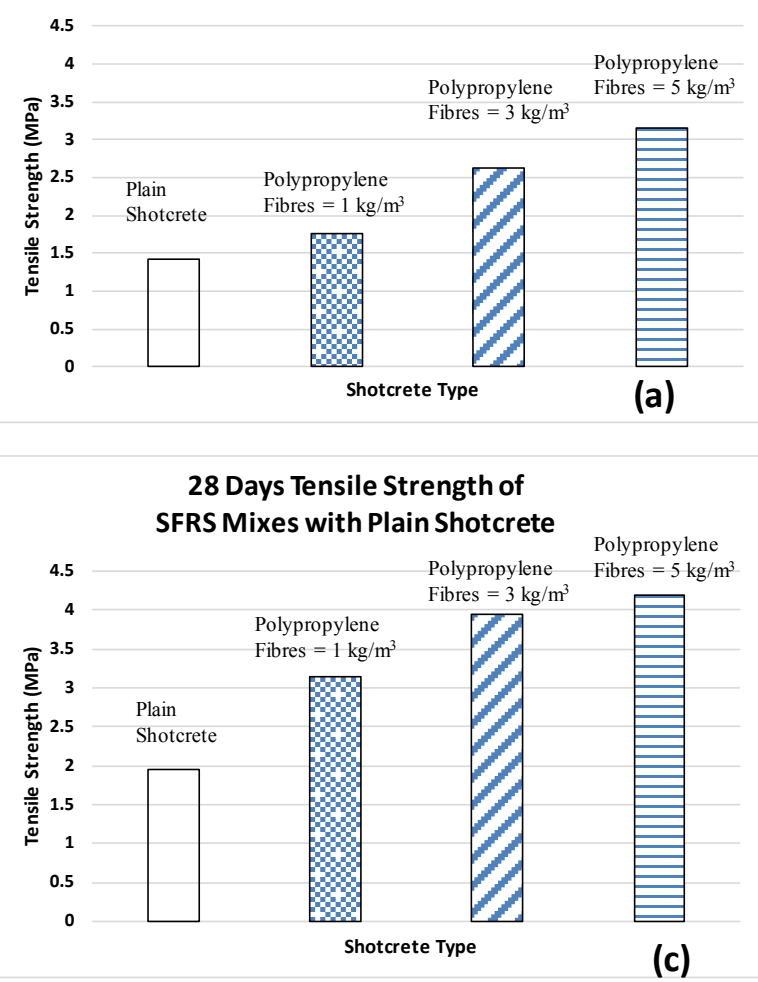

7 Days Tensile Strength of PFRS Mixes with Plain Shotcrete

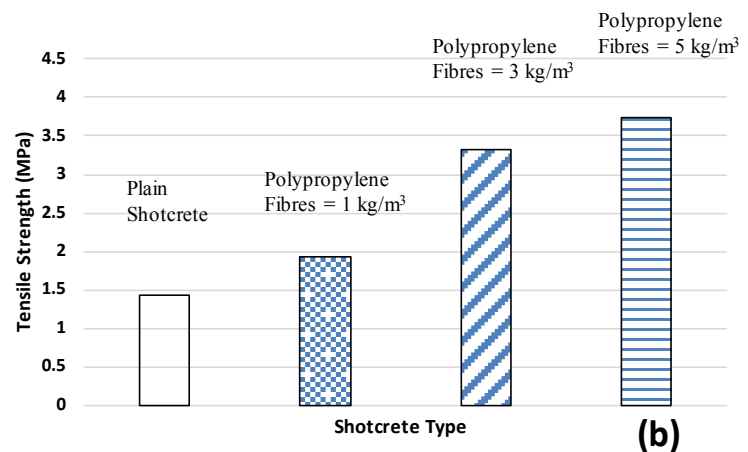

28 Days Tensile Strength of PFRS Mixes with Plain Shotcrete

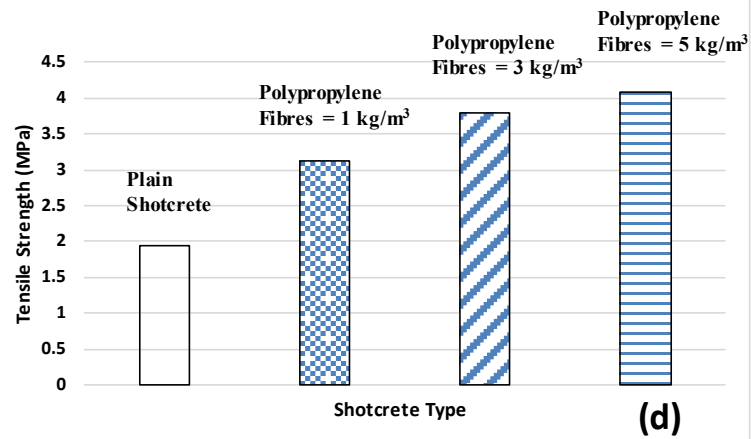

Figure 10. Comparison of the split tensile strength (a) 7 days using SFRS, (b) 7 days using PFRS, (c) 28 days using SFRS, and (d) 28 days using PFRS

The comparison of split tensile strength obtained for SFRS and PFRS for 7 days are shown by Figure 10 (a) and Figure 10 (b), respectively, whereas for 28 days are shown by Figure 10 (c) and Figure 10 (d).

The 7 days split tensile strength of cylinders without fibers is $1.4 \mathrm{Mpa}$, which varied from $24.4 \%$ to $121.2 \%$ for SFRS and $34.9 \%$ to $163.0 \%$ for PFRS, as shown in Table 3. Similarly, the 28 days split tensile strength of plain Shotcrete was 2.0 Mpa, whereas it varied from $61.26 \%$ to $114.4 \%$ for SFRS and $60.4 \%$ to $109.3 \%$ for PFRS, as mentioned in Table 3. The increase in the split tensile strength is relatively high when fibers are used in the Shotcrete.).

According to ASTM C 293 [17], in UTM, the flexural strength test is performed 24 in long beams with 6 in $x 6$ in cross-section. As shown in Figure 11, the failure pattern shows that it is split by the center point loading method.

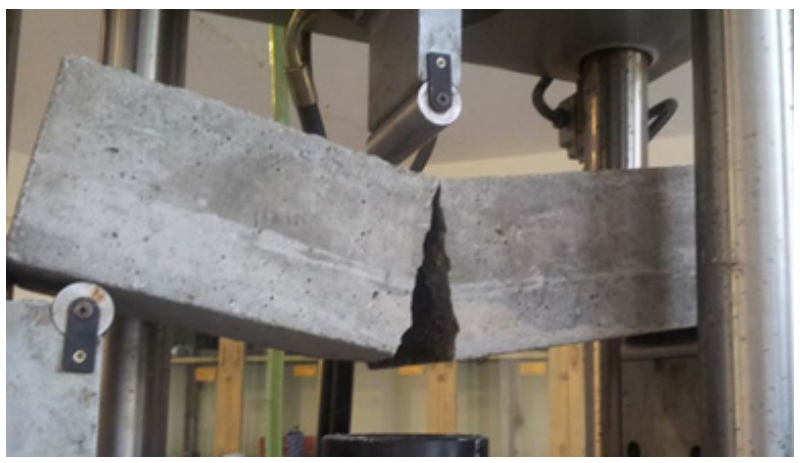

Figure 11. Failure of the beam during flexure test 
Table 4. Flexural Strength Test for 7- and 28-Days

\begin{tabular}{|c|c|c|c|c|c|}
\hline \multirow{2}{*}{$\begin{array}{c}\text { Type of } \\
\text { Shotcrete }\end{array}$} & $\begin{array}{c}\text { Fiber } \\
\left(\mathrm{kg} / \mathrm{m}^{3}\right)\end{array}$ & $\begin{array}{c}\text { Average } \\
\text { Flexural } \\
\text { strength } \\
\text { for 7 } \\
\text { days } \\
(\mathrm{MPa})\end{array}$ & $\begin{array}{c}\text { Percentile } \\
\text { Increase } \\
(\%)\end{array}$ & $\begin{array}{c}\text { Average } \\
\text { Flexural } \\
\text { strength } \\
\text { for 28 } \\
\text { days } \\
(\mathrm{MPa})\end{array}$ & $\begin{array}{c}\text { Percentile } \\
\text { Increase } \\
(\%)\end{array}$ \\
\hline $\begin{array}{c}\text { Plain } \\
\text { Shotcrete }\end{array}$ & 0.0 & 3.9 & - & 4.4 & - \\
\hline \multirow{3}{*}{ SFRS } & 40.0 & 4.3 & 11.2 & 7.0 & 58.9 \\
\cline { 2 - 6 } & 45.0 & 6.0 & 53.3 & 8.6 & 94.8 \\
\cline { 2 - 6 } & 50.0 & 7.0 & 80.0 & 9.1 & 106.0 \\
\hline \multirow{3}{*}{ PFRS } & 1.0 & 4.7 & 22.0 & 7.2 & 62.6 \\
\cline { 2 - 6 } & 3.0 & 7.6 & 94.7 & 8.5 & 92.0 \\
\cline { 2 - 6 } & 5.0 & 8.4 & 115.8 & 9.1 & 106.0 \\
\hline
\end{tabular}
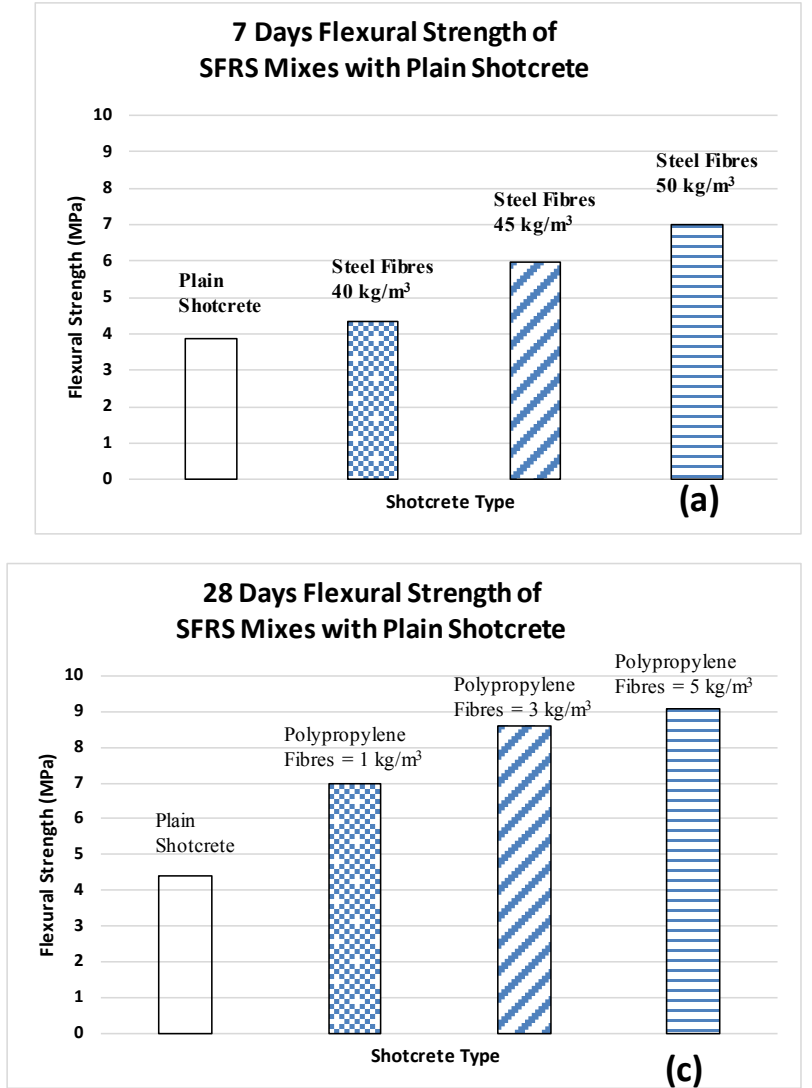

The 7- and 28-days flexural strength test results are presented in Table 4 for each type of Shotcrete.

The comparison of flexural strength obtained for SFRS and PFRS for 7 days is shown by Figure 12 (a) and Figure 12 (b), respectively, whereas for 28 days are shown by Figure 12 (c) and Figure 12 (d).

The 7 days flexural strength of beams without fibers is 3.9 Mpa and varies from $11.23 \%$ to $80.03 \%$ for SFRS and $22.0 \%$ to $115.8 \%$ for PFRS, refer to Table 4 . Similarly, the 28 days flexural strength of beams without fibers' addition is $4.4 \mathrm{Mpa}$ and varies from $58.85 \%$ to $105.95 \%$ for SFRS and $62.6 \%$ to $106.0 \%$ for PFRS, as shown in Table 4. The increase in flexural strength is due to the randomly oriented fibers that limit the crack propagation and therefore improve strength.
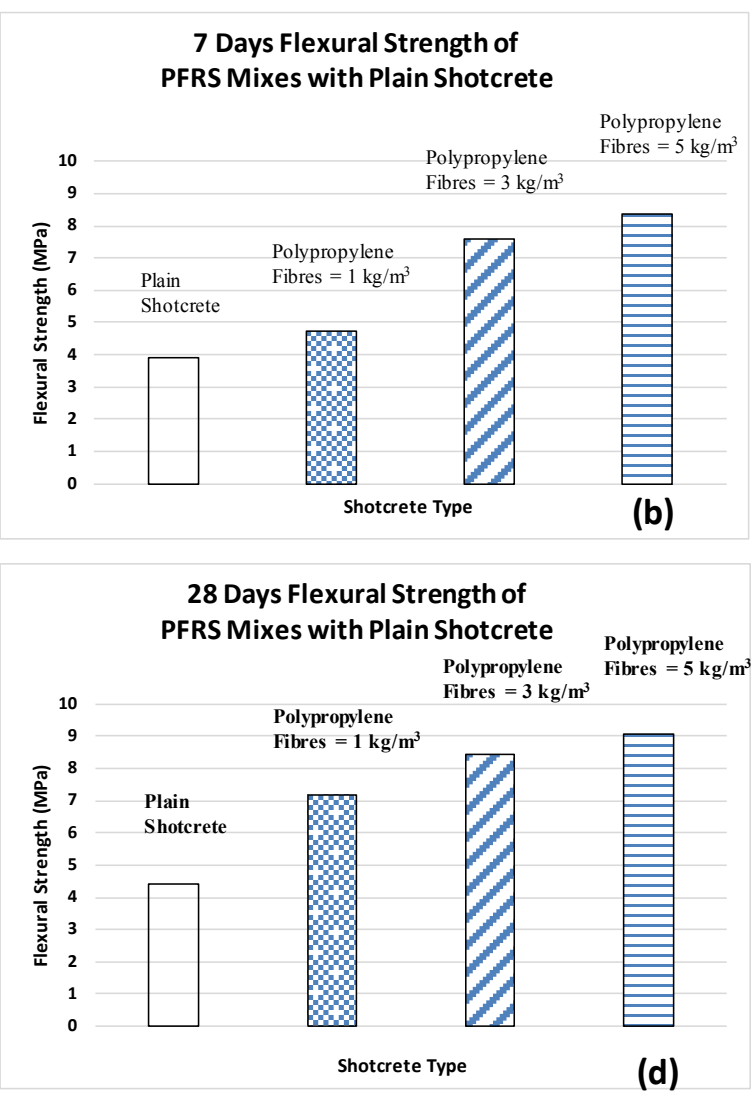

Figure 12. Comparison of flexural strength (a) 7 days using SFRS, (b) 7 days using PFRS, (c) 28 days using SFRS, and (d) 28 days using PFRS 


\section{Conclusions}

Shotcrete has indistinguishable properties to that of plain concrete. Adding polypropylene fibers up to $3 \mathrm{~kg} / \mathrm{m}^{3}$ showed a $20 \%$ increase in the compressive strength of Shotcrete. The compressive strength steadily diminished with the rise of fiber amount beyond $3 \mathrm{~kg} / \mathrm{m}^{3}$. With the increase of polypropylene fibers, the tensile and flexural strength increased. It was above $100 \%$ for $5 \mathrm{~kg} / \mathrm{m}^{3}$ of polypropylene fibers. This study showed that with the increase in steel fiber, the compressive, tensile, and flexure strength of Shotcrete is consistently attained. For $50 \mathrm{~kg} / \mathrm{m}^{3}$ of steel fibers, a $12 \%$ increase in compressive strength is recorded, and more than $100 \%$ tensile and flexure strength are achieved. It is appropriate to mention here that steel filaments in SFRS are more costly than polypropylene fibers in PFRS. The two fibers grant indistinguishable properties to Shotcrete, yet PFRS is less expensive when compared with Shotcrete. Still, the harmful properties of Polypropylene ought to be concentrated before their utilization in Shotcrete. Exceeding the polypropylene fiber quantity beyond a specific limit increases the tensile and flexural strength of Shotcrete with decreasing compressive strength. The reduction of compressive strength should be monitored carefully, and mix design should be changed accordingly.

\section{Abbreviations}

PFRS: Polypropylene Fiber, Reinforced Shotcrete

FRS: Fiber Reinforced Shotcrete

PP: Polypropylene Fibers

SFRS: Steel Fiber Reinforced Shotcrete

ASTM: American Society of Testing Materials

\section{Acknowledgments}

The support of laboratory staff at the University of Technology Peshawar is acknowledged.

\section{Conflict of Interest}

There is no relevant conflict of interest among the author regarding this paper.

\section{REFERENCES}

[1] "SME mining engineering handbook," Choice Rev. Online, 2011, doi: 10.5860/choice.49-0297.

[2] N. Banthia, V. Bindiganavile, J. Jones, and J. Novak, "Fiber-reinforced concrete in precast concrete applications: Research leads to innovative products," PCI J., 2012, doi: 10.15554/pcij.06012012.33.46.

[3] M. Di Prisco, G. Plizzari, and L. Vandewalle, "Fibre reinforced concrete: New design perspectives," 2009, doi: $10.1617 / \mathrm{s} 11527-009-9529-4$.

[4] S. Khoso, M. T. Naqash, S. Sher, and Z. Saeed, "An Experimental Study on Fiberly Reinforced Concrete using Polypropylene Fibre with Virgin and Recycled Road Aggregate," Archit. Civ. Eng. Environ., 2018, doi: 10.21307/acee-2018-007.

[5] X. Yan, L. M. Liu, J. P. Zhang, Y. H. Li, and H. Wang, "Experimental Study on Basic Mechanical Properties of Steel Fiber-Reinforced Siliceous Wet Shotcrete," $A d v$. Mater. Sci. Eng., 2018, doi: 10.1155/2018/1637261.

[6] A. Le Hoang and E. Fehling, "Influence of steel fiber content and aspect ratio on the uniaxial tensile and compressive behavior of ultra high performance concrete," Constr. Build. Mater., 2017, doi: 10.1016/j.conbuildmat.2017.07.130.

[7] S. Rahman and M. N. Uddin, "Experimental Investigation of Concrete with Glass Powder as Partial Replacement of Cement," Civ. Eng. Archit., vol. 6, no. 3, pp. 149-154, May 2018, doi: 10.13189/cea.2018.060304.

[8] S. Rahman, "Investigation on Mechanical Strength of Concrete Using Steel Bottle Caps as Fiber," Civ. Eng. Archit, vol. 7, no. 1, pp. 1-4, Jan. 2019, doi: 10.13189/cea.2019.070101.

[9] W. Abbass, M. I. Khan, and S. Mourad, "Evaluation of mechanical properties of steel fiber reinforced concrete with different strengths of concrete," Constr. Build. Mater., 2018, doi: 10.1016/j.conbuildmat.2018.02.164.

[10] P. T. Seabrook et al., "STATE-OF-THE-ART REPORT ON FIBER REINFORCED SHOTCRETE.," Concr. Int., 1984.

[11] G. Batson, "Steel fiber reinforced concrete," Mater. Sci. Eng., 1976, doi: 10.1016/0025-5416(76)90051-3.

[12] M. Leone, G. Centonze, D. Colonna, F. Micelli, and M. A. Aiello, "Fiber-reinforced concrete with low content of recycled steel fiber: Shear behaviour," Constr. Build. Mater., 2018, doi: 10.1016/j.conbuildmat.2017.11.101.

[13] K. A. Sheikh and A. Saif, "Steel Fibre-Reinforced Shotcrete as an alternative to conventional concrete tunnel lining: a case study of Gulpur Hydropower Project," Geomech. Geoengin., 2020, doi: 10.1080/17486025.2019.1639831.

[14] B. Z. Afridi, K. Shahzada, and M. T. Naqash, "Mechanical properties of polypropylene fibers mixed cement-sand mortar," J. Appl. Eng. Sci., 2019, doi: 10.5937/jaes17-1909 2.

[15] A. 820/A 820M-04, “A 820/A 820M-04 Standard Specification for steel fibers for fiber-reinforced concrete," ASTM, 2004.

[16] "ASTM C1604/C1604M-05 - Standard Test Method for Obtaining and Testing Drilled Cores of Shotcrete." https://webstore.ansi.org/Standards/ASTM/ASTMC1604C1 604M05 (accessed Nov. 20, 2020).

[17] ASTM International, “ASTM Standards C-293: Standard Test Method for Flexural Strength of Concrete (Using Simple Beam With Center-Point Loading)," Stand. Test Method Flexural Strength Concr. (Using Simple Beam With Center-Point Loading), 2002. 